\title{
Simulating future salinity dynamics in a coastal marshland under different climate scenarios
}

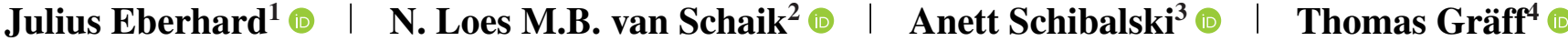

${ }^{1}$ Univ. Potsdam, Mathematisch-

Naturwissenschaftliche Fakultät, Institut für Physik und Astronomie, Potsdam, Germany

${ }^{2}$ Technische Univ. Berlin, Fakultät VI Planen Bauen Umwelt, Institut für Ökologie, Berlin, Germany

${ }^{3}$ TU Braunschweig, Fakultät Architektur,

Bauingenieurwesen und

Umweltwissenschaften, Institut für

Geoökologie, Braunschweig, Germany

${ }^{4}$ German Environment Agency, IV 2.1 Information Systems on Chemical Safety, Dessau-Roßlau, Germany

\section{Correspondence}

Anett Schibalski, TU Braunschweig, Fakultät Architektur, Bauingenieurwesen und Umweltwissenschaften, Institut für Geoökologie, Braunschweig, Germany

Email:a.schibalski@tu-braunschweig.de

Funding information

Sustainable coastal land management: Tradeoffs in ecosystem services COMTESS,

Grant/Award Number: 01LL0911; German Research Foundation; Open Access Publication Funds of the Technische Universität Braunschweig

\begin{abstract}
Salinization is a well-known problem in agricultural areas worldwide. In the last 20$30 \mathrm{yr}$, rising salinity in the upper, unconfined aquifer has been observed in the Freepsumer Meer, a grassland near the German North Sea coast. For investigating long-term development of salinity and water balance during 1961-2099, the one-dimensional Soil-Water-Atmosphere-Plant (SWAP) model was set up and calibrated for a soil column in the area. The model setup involves a deep aquifer as the source of salt through upward seepage. In the vertical salt transport equation, dispersion and advection are included. Six different regional outputs of statistical downscaling methods were used as climate scenarios. These comprise different rates of increasing surface temperature and different trends in seasonal rainfall. The simulation results exhibit opposing salinity trends for topsoil and deeper layers. Although projections of some scenarios entail decreasing salinities near the surface, most of them project a rise in subsoil salinity, with the strongest trends of up to $+0.9 \mathrm{mg} \mathrm{cm}^{-3} 100 \mathrm{yr}^{-1}$ at $-65 \mathrm{~cm}$. The results suggest that topsoil salinity trends in the study area are affected by the magnitude of winter rainfall trends, whereas high subsoil salinities correspond to low winter rainfall and high summer temperature. How these projected trends affect the vegetation and thereby future land use will depend on the future management of groundwater levels in the area.
\end{abstract}

\section{1 | INTRODUCTION}

For decades, soil salinization has been discussed intensely as a global threat to agricultural production (Fedoroff et al., 2010; Maas \& Hoffman, 1977; McWilliam, 1986). Yields decrease under saline conditions when high-yield crops are salt intolerant (Maas \& Grattan, 1999), and halophytes used

Abbreviations: ET, evapotranspiration; PTF, pedotransfer function; RCP, Representative Concentration Pathway; SRES, Special Report on Emission Scenarios; SWAP, Soil-Water-Atmosphere-Plant. as fodder (Masters, Benes, \& Norman, 2007), as well as saline drinking water, may lead to lower dairy production (Solomon, Miron, Ben-Ghedalia, \& Zomberg, 1995). Great efforts are being made to counteract the negative effects of salinization (e.g., by breeding salt-tolerant crop and fodder species; Flowers, 2004; Glenn, Brown, \& Blumwald, 1999; Panta et al., 2014; Rozema \& Flowers, 2008; Yamaguchi \& Blumwald, 2005; Yensen, 2006).

In the past, research focused mainly on management options for salinization (Ghassemi, Jakeman, \& Nix, 1995) caused by irrigation in arid regions (Pitman \& Läuchli, 2002;

This is an open access article under the terms of the Creative Commons Attri the original work is properly cited, the use is non-commercial and no modifications or adaptations are made.

(C) 2020 The Authors. Vadose Zone Journal published by Wiley Periodicals, Inc. on behalf of Soil Science Society of America 
Rengasamy, 2006), which is amplified by climate change (Yeo, 1999); this is the so-called secondary salinization. Issues involving saline irrigation water in other regions have also been addressed more recently (Pauw, van Baaren, Visser, de Louw, \& Oude Essink, 2015). Primary salinization, on the other hand, is caused by sea spray, floodings (Violette, Boulicot, \& Gorelick, 2009) and seawater intrusion (Werner et al., 2013) and is thus confined to coastal areas around the globe (e.g., Bangladesh, Haque, 2006; Korea, Kim et al., 2003). Although primary salinization may not currently be as problematic as secondary salinization, rising sea levels will aggravate the issue as shown by recent changes in coastal vegetation (Williams, Ewel, Stumpf, Putz, \& Workman, 1999). Coastal marshlands in Europe are examples of intensively used agricultural landscapes, which are threatened by rising sea levels and climate change (Bakker et al., 1993). Ground and surface water in these regions can be affected by primary salinization in several ways. Seawater intrusion into deep aquifers may occur because marshland sediments are typically horizontally layered and often form well-connected aquifers (Streif, 1990). The inhomogeneous geological setup, which consists of Holocene peats, clays, and sand structures in varying thickness, affects the saltwater intrusion from deeper aquifers (de Louw, Eeman, Oude Essink, Vermue, \& Post, 2013; de Louw, Oude Essink, Stuyfzand, \& van der Zee, 2010; de Louw, van der Velde, \& van der Zee, 2011; Herbert et al., 2015; Oude Essink, van Baaren, \& de Louw, 2010). Apart from salt import from deeper layers, the salt concentration in a soil increases through evaporation and plant transpiration, whereas it decreases through precipitation and subsequent infiltration (de Louw et al., 2013). Thus, it is important to understand how these types of soils react to changing meteorological conditions with a potential increase in dryness and higher temperatures. In the long term, water from deep aquifers can seep upward to the soil through halfconfining layers (aquitards; de Louw et al., 2010). In the short term, greater effects can result from small and local defects in the aquitard (boils; de Louw et al., 2010), and filled up former tideways that cut through confining layers (paleochannels; Weerts, 1996). Storm surges possibly affect the salinity of coastal marshlands in cases of dike failures, as floods can spread quickly over the flat surface (Miegel et al., 2016). Additionally, sea spray can contribute to the salinization of surface water (Stuyfzand \& Stuurman, 2008). Apart from salt import, the salt concentration in a soil increases through evaporation and plant transpiration, whereas it decreases through precipitation and subsequent infiltration (de Louw et al., 2013). Water management may further alter the soil salinity through pumping. Thus, the water balance additionally influences the temporal development of the salinity in a soil profile. Under climate change, different water balance components are expected to be subject to long-term changes (Jiménez Cisneros et al., 2014) and therefore may cause longterm shifts in the salinity of coastal areas.

\section{Core Ideas}

- We simulated future salinity dynamics with six different climate change scenarios.

- We find differing salinity trends for topsoil and deeper layers.

- Salinity trends depend on a combination of changed ET and summer and winter rainfall.

- An increase in ET in summer leads to higher salinity if rainfall decreases.

- An increase in summer and winter precipitation can limit the effect of increased ET.

As Kliesch, Behr, Salzmann, and Miegel (2016) pointed out, quantitative investigations of the processes involved in the salinization of coastal aquifers in many regions are just beginning. A study in the Netherlands showed the possible influence of rising temperatures, changing rainfall patterns, and sea-level rise on coastal salinity (Oude Essink et al., 2010). The authors concluded that rising groundwater salinities should be expected as a result of climate change, with a particularly strong effect on subsiding areas such as polders. They used a large-scale model, which allowed for general answers to regional management questions on the Dutch coast. Other recent studies in Italy and Germany used smallor medium-scale models on mostly sandy aquifers (Colombani, Mastrocicco, \& Giambastiani, 2015; Kliesch et al., 2016) and also predicted rising surface salinities. Regarding small-scale processes, salinization through boils in coastal marshlands was investigated by de Louw et al. (2010). However, boils are rarely observed, and other small-scale processes such as rainfall infiltration, evapotranspiration (ET), and upward seepage through locally thin aquitards may dominate the salt balance. Local models with a high spatial resolution can be helpful in the detailed understanding of these processes (Delsman, de Louw, de Lange, \& Oude Essink, 2017).

In this study, we investigate the long-term effects of climate change on slow salinization by upward seepage of deep groundwater, which we expect to be the main cause of salinization in our study area, the Freepsumer Meer. We use the one-dimensional Soil-Water-Atmosphere-Plant (SWAP) model (van Dam, 2000), which allows for a specific parametrization of most processes (for details on the SWAP model and parametrization, see Sections 2.2 and 2.3), which are relevant for water and solute transport in the soil column and is currently widely used in studies concerning, for example, evapotranspiration (Bartholomeus, Stagge, Tallaksen, \& Witte, 2015; Minacapilli et al., 2009), surface water management (Schipper et al., 2015), plant growth (Bonfante et al., 2017), and salinization (Kumar, Sarangi, Singh, Parihar, \& Sahoo, 2015). We use long-term simulations with six different climate change scenarios with differing trends in 
(a)

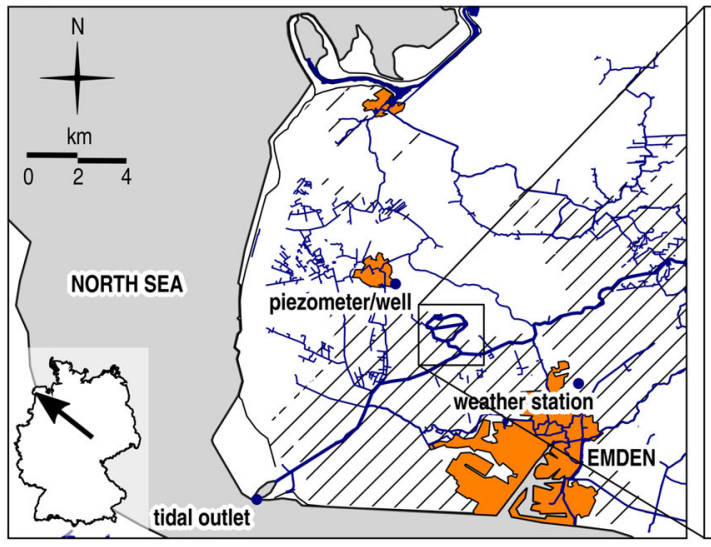

(b)
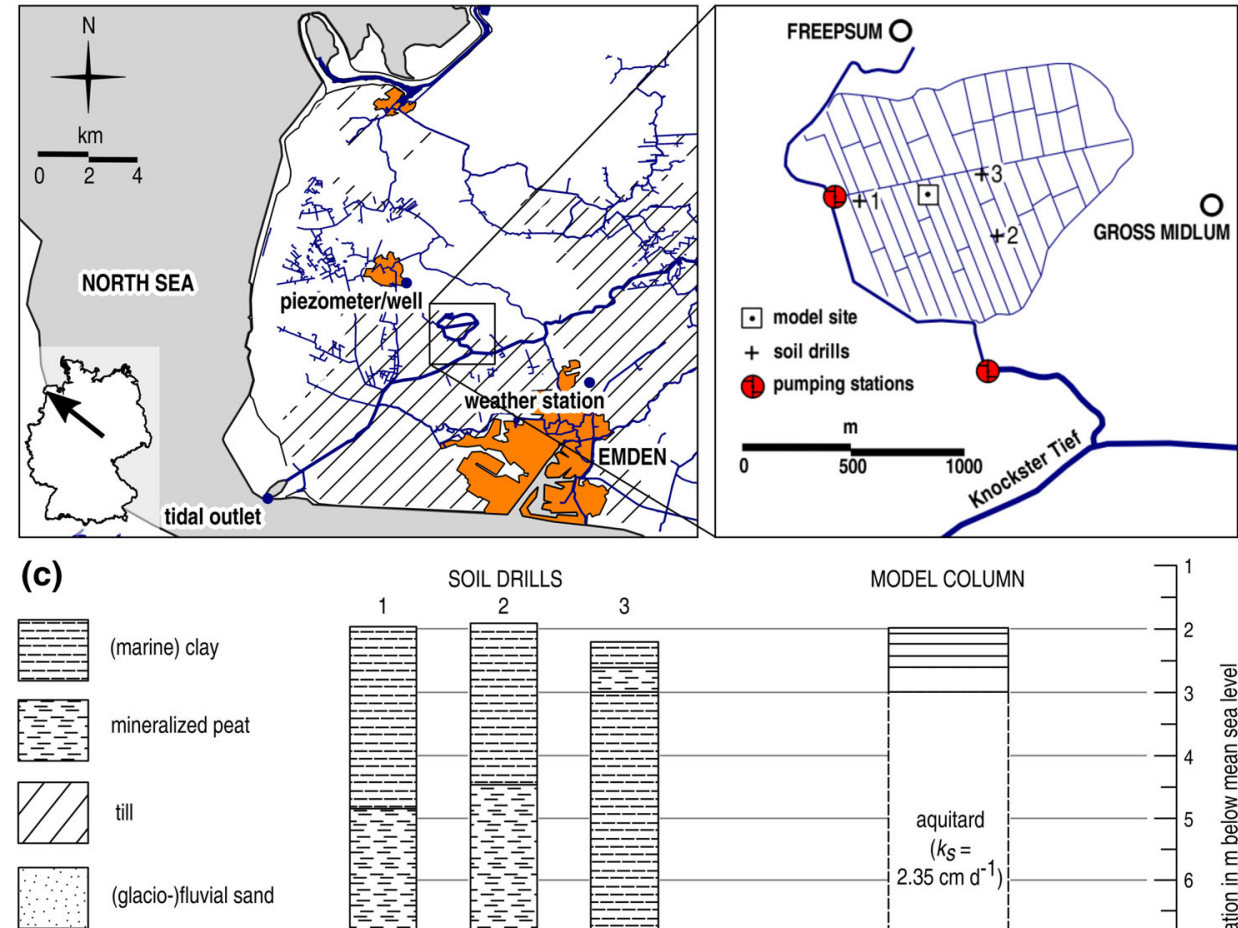

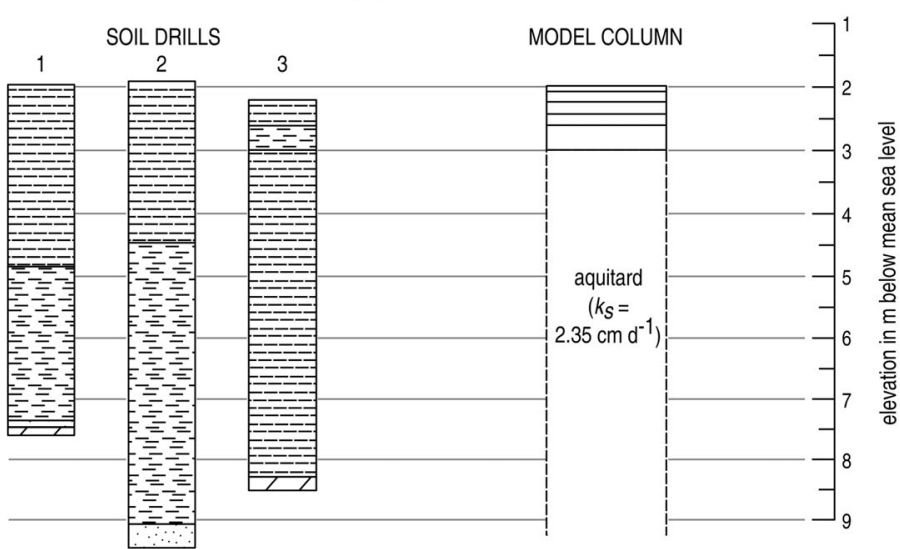

F I G U R E 1 Overview of the study area. (a) Location of the Freepsumer Meer within the Krummhörn region (blue lines: water courses, including the ones shown in Panel b [thick]; thin black lines along the coast: dikelines; orange areas: major settlements; hatched areas: surface beneath mean sea level). (b) Location of the model site, soil drills, and surface drainage structure (blue lines) of the Freepsumer Meer. The Freepsumer Meer is a former lake and lies, on average, $1.5 \mathrm{~m}$ below the surrounding area. The elevation of the surface drains is marked using the thickness: the lowest drains the thinnest lines, highest drains the thickest. (c) Soil drills representing the geological structure of the region: clay layers on top of (glacio-)fluvial sand with intermediate peat (Wildvang, 1938); on the right, the model column as used in the model. The saturated hydraulic conductivity $\left(k_{\mathrm{s}}\right)$ is also shown

surface temperature and seasonal precipitation. We compare the water balance and salinity output of the models for a quantitative analysis of projected salinity dynamics.

This study was performed in close collaboration with the research project COMTESS (Sustainable coastal land management: Trade-offs in ecosystem services). In this project, the impact of climate change, sea-level rise, and different land management options on hydrological conditions, the distribution of coastal vegetation, and provision of ecosystem services in coastal areas is investigated (Karrasch, Maier, Klenke, \& Kleyer, 2017).

\section{2 | MATERIALS \& METHODS}

\section{1 | Study area}

The Freepsumer Meer is a former lake in the Krummhörn municipality, north of Emden in northwestern Germany, $\sim 8 \mathrm{~km}$ off the coast of the North Sea (Figure 1a). It contains the lowest measured point of the region, which is $2.3 \mathrm{~m}$ below sea level. This region is a low-lying marshland and is artificially decoupled from surrounding water bodies by dikes. The area consists of small lots divided by numerous drain ditches. No point of the surface has a greater distance than $\sim 100 \mathrm{~m}$ to the next ditch. The area is continuously drained through the management of the water level in the surface ditches, which in turn are kept almost constant by the nearby pumping station (Figure 1b). Thus, water is only pumped out of the area to the main water courses, and there is no direct surface water connection back from those water courses into the area. Any horizontal groundwater fluxes are dominated by the local surface drainage. Lateral intrusion of saltwater to the unconfined aquifer is not an issue here. As a result, the main mechanism causing the observed salinization must be the upward seepage, despite the clayey soil and the peaty aquitard (Figure 1c). Therefore, the water and salt balance are determined by the one-dimensional bottom flux through the aquitard, the lateral 
drainage, and the climate conditions at the top. No subsurface drainage occurs in the area. Today the Freepsumer Meer is used mainly as grassland.

Upward seepage of deep groundwater is not directly apparent from the geological configuration of the region. The thin silty upper layer, which we consider here as the unconfined aquifer, lies on top of an up to 6-m-thick layer of clay, followed by the sandy lower aquifer (Figure 1c). Typical for the site are layers of strongly mineralized Holocene peat between the clay and the sand. This basal peat is found beneath the Freepsumer Meer but is interrupted in the eastern part (Wildvang, 1938). Both clay and peat layers form an aquitard with a typically low hydraulic conductivity (Verry et al., 2011). Nonetheless, salinization of the Freepsumer Meer has been observed from measurements of the surface water quality starting in 1985. The marshland of the old lake system is strongly compacted, compared with the surrounding younger marshland. As a result, the area is subject to subsidence (Streif, 1990) reducing the load on lower aquifers and thus increasing the vertical pressure gradient, which can drive upward seepage.

We tried to account for the observed situation by assuming an aquitard between the sand and the unconfined aquifer. We allowed for upward seepage through the aquitard and estimated its effective hydraulic resistance through calibration.

\section{2 | Model}

The SWAP model was developed at Wageningen University as a tool for simulating processes regarding water, heat, and solute transport in the soil-water-atmosphere-plant environment, mainly in the unsaturated zone of soils (van Dam, 2000). The SWAP model numerically solves the Richards equation (Richards, 1931), which describes mass and energy conservative flow of water in a vertical soil column.

Processes that affect the water balance and are included in SWAP are water movement between soil particles (infiltration, percolation, and capillary rise), ET, rainfall interception, surface runoff, bottom flux, plant uptake, drainage, and macropore exchange. Soil hydraulic characteristics are described with the Mualem-van Genuchten equation (Mualem, 1976; van Genuchten, 1980), which relates the hydraulic conductivity $k$ (in units of $\mathrm{cm} \mathrm{d}^{-1}$ ) of a soil layer to its water retention curve. The vertical salt transport equation combines the processes of diffusion, dispersion, advection, and salt uptake by plant roots:

$$
\frac{\partial c}{\partial t}=\frac{\partial}{\partial z}\left[\Theta_{\mathrm{s}}\left(D_{\mathrm{dif}}+q L_{\mathrm{dis}}\right) \frac{\partial c}{\partial z}\right]-\frac{\partial}{\partial z}(q c)-S_{\mathrm{root}}
$$

where $c$ is the solute concentration $\left(\mathrm{mg} \mathrm{cm}^{-3}\right), t$ is the time (d), $z$ is the elevation $(\mathrm{cm}), \Theta_{\mathrm{s}}$ is the saturated water content or porosity $\left(\mathrm{cm}^{3} \mathrm{~cm}^{-3}\right), D_{\text {dif }}$ is the vertical diffusion coefficient $\left(\mathrm{cm}^{2} \mathrm{~d}^{-1}\right), q$ is the vertical Darcy velocity $\left(\mathrm{cm} \mathrm{d}^{-1}\right), L_{\mathrm{dis}}$ is the vertical dispersion length $(\mathrm{cm})$, and $S_{\text {root }}$ is the salt uptake rate of plant roots $\left(\mathrm{mg} \mathrm{cm} \mathrm{cm}^{-3} \mathrm{~d}^{-1}\right)$.

We simulated daily water contents, pressure heads, and salt concentrations at discrete depths of one-dimensional soil columns, as well as water balance components including ET and bottom fluxes.

\subsection{Input data and model parameters}

The SWAP model requires $>100$ parameters referring to model setup and numerics, meteorology, crop growth, soil water conditions and transport, lateral drainage, bottom boundary conditions, heat flow, and solute transport. The model was developed for an area with very similar climate and geological settings as our study area. Therefore, we used default values for all parameters that are not further specified in the manuscript.

The geometry of the model domain was defined by the vertical extent of the soil columns, the horizontal distances to drain ditches, and their shape. Measurements of soil physical properties were available for depths up to $-80 \mathrm{~cm}$ relative to the surface. Since the groundwater level dropped below $-80 \mathrm{~cm}$ in some model runs, we needed to specify a model column with additional $20 \mathrm{~cm}$ of depth for which we assumed the physical properties to be equal to those at $-80 \mathrm{~cm}$. The distances and shapes of the ditches were recorded during field measurements for this study.

For driving the model at the upper boundary, we obtained daily data on temperature, wind, rainfall, and relative humidity for the Emden weather station (location in Figure 1a) from the German Meteorological Service (Deutscher Wetterdienst, DWD). Daily global radiation data were provided by https://wetter-ostfriesland.de. We used daily measurements of pressure heads in the confined aquifer from a nearby well (Figure 1a) as the bottom boundary condition for upward groundwater seepage. The salinity of the confined groundwater is given as a constant parameter $\left(6.6 \mathrm{mg} \mathrm{cm}^{-3}\right)$ in the model and was estimated in the model calibration (for details on the calibration method, see Section 2.4). Any additional salt import through storm surges and sea spray was ignored in the boundary conditions, as these processes are expected to be negligible due to the distance of the area from the North Sea coast. The water board I. Entwässerungsverband Emden provided data of the managed mean surface water level.

The SWAP model includes a simple, as well as a detailed, crop growth scheme (Kroes, Wesseling, \& van Dam, 2000). We chose the simple scheme and specified the crop schedule as a fixed cycle of 1-yr length with constant plant parameters.

Soil and plant parameter values were either taken from the literature (including those suggested in the SWAP 
T A B L E 1 Numerical resolution, values of Mualem-van Genuchten parameters, and lateral boundary parameters used in the model

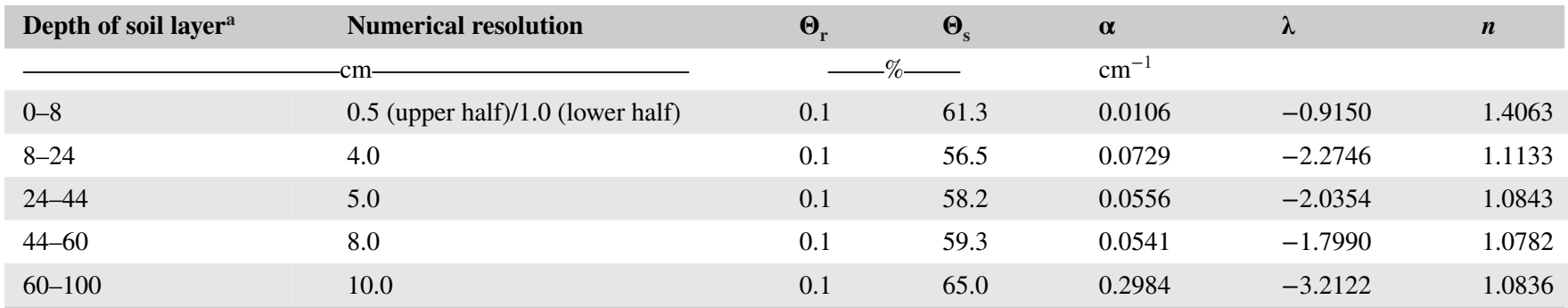

Note. Residual water content $\left(\Theta_{\mathrm{r}}\right)$ was set to $0.1 \%(\mathrm{v} / \mathrm{v})$, which was the minimum observed soil moisture content in the area. Saturated water content $\left(\Theta_{\mathrm{s}}\right)$ was based on onsite measurements (Supplemental Table S1) following Waller \& Harrison (1986) and Rühlmann et al. (2005). Finally, Mualem-van Genuchten parameters $\alpha, \lambda$, and $n$ were derived from onsite measurements using pedotransfer functions after Wösten et al. (1999).

${ }^{a}$ Mean drain base $=-101 \mathrm{~cm}$. Groundwater level for maximum infiltration $=-110 \mathrm{~cm}$. Entry-exit resistance $=1 \mathrm{~d}$. Drainage infiltration resistance $=50 \mathrm{~d}$.

manual; Kroes, van Dam, Groenendijk, Hendriks, \& Jacobs, 2008), modeled by pedotransfer functions (PTFs), or directly or indirectly measured. Data of geodetic height, grain size distribution, soil organic matter, soil layer thickness, and bulk density were available from measurements for previous studies (Witte \& Giani, 2016). Since SWAP was originally set up and tested in the Netherlands (Kroes et al., 2000) with similar environmental conditions to our study area, we adopted default parameter values (Kroes et al., 2008) where we had no additional information, which applies to all parameters not specified here.

The simulated soil profile consists of five soil layers, which are implemented with decreasing numerical resolution with depth (Table 1). We derived the saturated water content $\Theta_{\mathrm{s}}$ $\left(\mathrm{cm}^{3} \mathrm{~cm}^{-3}\right.$, Table 1) from onsite measurements (Supplemental Table S1) following Waller and Harrison (1986) and Rühlmann, Körschens, and Graefe (2005). Recorded grain size distribution, organic $\mathrm{C}$ content, and bulk density (Supplemental Table S1) were used to estimate the other Mualemvan Genuchten parameters $\lambda(-), \alpha\left(\mathrm{cm}^{-1}\right), n(-)$, and residual water content $\Theta_{\mathrm{r}}\left(\mathrm{cm}^{3} \mathrm{~cm}^{-3}\right)$ with PTFs. Where $\Theta_{\mathrm{r}}$ was 0 according to the PTF, we used a value of 0.1 , which is the minimum of the observed water content in the region. We compared three PTFs by Rawls and Brakensiek (1985), Wösten, Lilly, Nemes, and le Bas (1999), and Weynants, Vereecken, and Javaux (2009) regarding their fit in the model calibration (data following Wösten et al., 1999; Table 1). Saturated hydraulic conductivity $k_{\mathrm{s}}\left(\mathrm{cm} \mathrm{s}^{-1}\right)$ had to be estimated separately instead of being taken from the PTFs for two reasons. First, the high variability of hydraulic conductivity for given soil properties makes indirect predictions of $k_{\mathrm{S}}$ through transfer functions prone to error (Dai, Shangguan, \& Duan, 2013). Secondly, although macropores have been observed in the field, we did not have the necessary data to explicitly parameterize macropore flow in SWAP. Therefore, we estimated lumped effective $k_{\mathrm{s}}$ values in the calibration. Amoozemeter measurements of $k_{\mathrm{s}}$ in the neighborhood of the plot (Supplemental Table S2) provided the basis for the calibration range of $k_{\mathrm{s}}$.
TA B L E 2 Values of calibrated parameters. Calibration ranges are included in parentheses

\begin{tabular}{lll} 
Depth of soil layer & $\boldsymbol{k}_{\mathrm{s}}{ }^{\mathbf{a}}$ & $\boldsymbol{L}_{\mathrm{dis}}{ }^{\mathbf{b}}$ \\
\hline $\mathrm{cm}$ & $\mathrm{cm} \mathrm{d}^{-1}$ & $\mathrm{~cm}$ \\
\hline $0-24$ & $20.2(1.0-100.0)$ & $25(1-70)$ \\
\hline $24-100^{\mathrm{c}}$ & $2.4(1.0-20.0)$ & $60(1-70)$ \\
\hline
\end{tabular}

${ }^{\mathrm{a}} k_{\mathrm{s}}$, saturated hydraulic conductivity.

${ }^{\mathrm{b}} L_{\mathrm{dis}}$, vertical dispersion length.

${ }^{\mathrm{c} S}$ alt concentration in deep aquifer $(>100 \mathrm{~cm})=6.6(6.0-11.0) \mathrm{mg} \mathrm{cm}^{-3}$. Vertical aquitard resistance $=500(100-500) \mathrm{d}$.

Plant parameters for grassland were mainly adopted from example input files provided by the model developers. We sampled rooting depths in field measurements and chose the mean as the model parameter. Maximum rooting depths were derived from the soil profiles, assuming that anoxic conditions in the lower horizons restrict root growth (Taylor \& Ashcroft, 1972).

We calculated ET rates from potential rates following Penman and Monteith (Monteith, 1965), and the rates were split into plant transpiration and soil evaporation by leaf area index (2.5, default). Actual rates were obtained by stress functions for transpiration and by maximum soil water flux and the Boesten-Stroosnijder reduction (Boesten \& Stroosnijder, 1986) for soil evaporation, using default parameters (Kroes et al., 2008).

The simulated groundwater level is, after its initialization, determined by the given boundary conditions (i.e., the specified pressure head in the deep aquifer [Dirichlet type bottom boundary condition]), the prescribed water levels in the drain ditches, and geometry and hydraulic properties of the field (lateral boundary condition). Drainage fluxes through different parts of the model domain are characterized by various resistances that are listed in Tables 1 and 2. Every resistance value can be understood as the ratio $d / k_{\mathrm{s}}$, where $d$ is the distance which the water passes during drainage $(\mathrm{cm})$. Resistances therefore have a unit of time. The values of horizontal drainage and infiltration resistances were chosen based 
on the distances between model columns and ditches and the averages of observed $k_{\mathrm{s}}$ in the subsoil (i.e., below $-30 \mathrm{~cm}$, Table 1). The resistance of the aquitard was estimated in the model calibration.

Following Equation 1, the relevant parameters for salt transport are the dispersion length $L_{\text {dis }}$, the constant groundwater salinity beneath the soil column, the diffusion coefficient, and the root uptake rate. Since diffusion and root uptake are negligible under the given circumstances (Kroes et al., 2008), they were set to zero a priori.

For the examined site, observations of groundwater level ( $\mathrm{cm}$ below surface) and electric conductivity (EC, $\mathrm{mS} \mathrm{cm}^{-1}$ ) over a period of 14 mo were available. We calculated salinities from the EC observations by linear regression ( $c=0.54 \mathrm{mg}$ $\mathrm{cm}^{-2} \mathrm{mS}^{-1} \times \mathrm{EC}$ ) of data from a nearby well (Figure 1a). In contrast with daily model output, the temporal resolution of the observations was $\sim 2 \mathrm{wk}$. In order to reduce the effect of the different resolutions in the calibration and validation, we smoothed the model output by applying a left-sided running 2-wk mean.

\section{$2.4 \mid$ Calibration}

We conducted a simple sensitivity analysis for parameters with uncertain or unknown values. The parameters for which the model was most sensitive were chosen for model calibration: saturated hydraulic conductivity $\left(k_{\mathrm{s}}\right)$, dispersion length $\left(L_{\text {dis }}\right)$, salinity in the confined aquifer, and vertical aquitard resistance. We estimated these parameters using the smoothed model output and the observations of groundwater level and salinity. In our study area, we have a typical condition of high groundwater levels and a clayey and peaty soil, which leads to generally near-saturated conditions in the unsaturated zone with only limited fluctuations. Additionally, measurements of soil moisture content in such soils with high clay and organic matter content and high salinity are problematic and uncertain. Therefore, we chose to measure the groundwater level and salinity in the groundwater to use for the model calibration.

The parameter calibration was performed in three steps. First, the parameters saturated hydraulic conductivity $\left(k_{\mathrm{s}}\right)$, dispersion length $\left(L_{\text {dis }}\right)$, deep groundwater salinity, and vertical resistance were estimated with the aim to minimize the sum of squared deviations between the simulated and measured groundwater levels. For this purpose, we used the PEST software package (Doherty, 2010). This is a software package for model-independent parameter estimation and uncertainty analysis and uses a steepest decent searching optimization algorithm based on Gauss-Marquardt-Levenberg (Doherty, 2010). Second, the value of the deep groundwater salinity was varied, leaving all other parameters as estimated in the previous step. In this process, single events of the measured
T A B L E 3 General circulation models (GCMs), statistical downscaling methods (SDMs), and greenhouse gas scenarios used for computation of the weather scenarios

\begin{tabular}{|llll} 
Scenario & GCM & SDM & Greenhouse gas scenario \\
\hline I & ECHAM5 & WETTREG & SRES-A2 \\
II & ECHAM5 & WETTREG & SRES-B1 \\
\hline III & ECHAM6 & XDS & RCP4.5 \\
IV & ECHAM6 & XDS & RCP8.5 \\
V & IPSL-CM5 & XDS & RCP4.5 \\
VI & IPSL-CM5 & XDS & RCP8.5 \\
\hline
\end{tabular}

salinity had a large impact on the objective function. Although having the smallest numerical error, the observed dynamics seemed to be not well represented by the calibrated model run. Therefore, we visually compared the subseasonal dynamics and values of the observations with those of the simulation results for a small range of deep groundwater salinities around the numerically estimated value. The final value was chosen because it led to the best reproduction of the observations and their dynamics. After the previous steps were performed for each of the three PTFs, the subannual dynamics of each were compared (locations of local minima and maxima, ranges of submonthly fluctuations). The PTF of Wösten et al. (1999) was chosen, as this led to the best reproduction of the medium-term dynamics of both groundwater level and salinity. Multiple calibrations yielded different parameter sets with best accordance of simulated and observed groundwater levels. From those we chose the parameter set for which salinity could also be represented best (Table 2). For the final calibrated model, the sum of squared deviations between modeled and observed groundwater levels is $694.8 \mathrm{~cm}^{2}$. The mean deviation per observation is $2.0 \mathrm{~cm}$. The correlation coefficient of modeled and observed groundwater levels is .76.

\section{5 | Scenarios}

In order to study the influence of possible future climate changes, we compared the effects of six different weather scenarios (Table 3 ) on salinity and water balance components. The chosen climate scenarios were specifically developed for this region. These scenarios cover time series of radiation, minimum and maximum temperature, air humidity, wind speed, and rainfall. These data were obtained by the statistical downscaling methods WETTREG (Spekat, Kreienkamp, \& Enke, 2010) and XDS (Bürger, 1996) in combination with the general circulation models ECHAM5 (Roeckner et al., 2003), ECHAM6 (Stevens et al., 2013), and IPSL-CM5 (Dufresne et al., 2013). Scenarios I and II involve greenhouse gas emission scenarios from the A2 and B1 families of the Special Report on Emission Scenarios (SRES; Nakićenović \& 


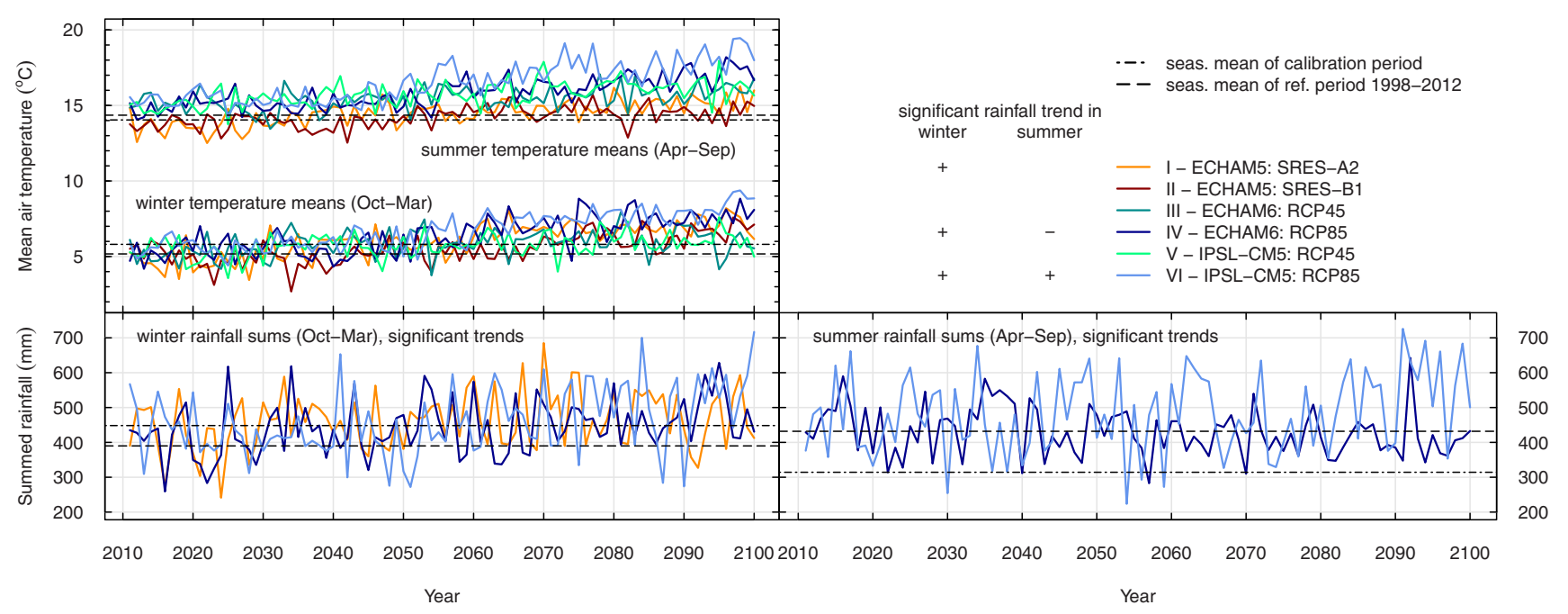

F I G U R E 2 Seasonal (seas.) mean temperatures and rainfall sums in Scenarios I-VI (2011-2100). Comparison between the means of the calibration period (October 2011-December 2012), the means of a reference period (1998-2012), and the scenario inputs. Only time series with significant trends (Mann-Kendall test, $p<5 \%$ ) are shown. All temperature scenarios have significant positive trends. Winter means were calculated for the periods from October to March, and summer means were calculated for the periods from April to September. RCP, Representative Concentration Pathway; SRES, Special Report on Emission Scenarios

Swart, 2000). In direct comparison, A2 scenarios are characterized by a regionally oriented economic development and a higher global population growth, whereas B1 scenarios follow a storyline of a more global economic growth and a lower population growth. In contrast with the SRES scenarios, in the Representative Concentration Pathway (RCP) scenarios the greenhouse gas emissions are decoupled from socioeconomic models (Moss et al., 2008). Instead, a range of possible future $\mathrm{CO}_{2}$ emissions and radiative forcing trends until 2100 are used. Thus, the RCP4.5 and RCP8.5 scenarios correspond to an increase in radiative forcing of +4.5 and $+8.5 \mathrm{~W} \mathrm{~m}^{-2}$, respectively, in 2100 compared with preindustrial values. The SRES emission scenarios were used in the Fourth Assessment Report (AR4) of the Intergovernmental Panel on Climate Change (IPCC), whereas the RCP scenarios were used in the Fifth Assessment Report (AR5). The differences in the trends in temperature and precipitation for the resulting six scenarios are described in the paragraphs below.

Summer means of the 2011-2100 temperature differ distinctly between SRES Scenarios I and II (14.5 and $\left.14.2^{\circ} \mathrm{C}\right)$ and RCP scenarios (between 15.5 and $16.5^{\circ} \mathrm{C}$ ). Corresponding winter means (all between 5.5 and $6.7^{\circ} \mathrm{C}$ ) show no similar tendency. Interscenario differences between 2011 and 2100 summer means also occur in annual rainfall, for which Scenarios I and II have lower values (392.3 and $376.2 \mathrm{~mm}$ ) than the other scenarios (between 434.1 and $481.9 \mathrm{~mm}$ ). As well as temperature, mean annual winter rainfall (between 442.5 and $462.4 \mathrm{~mm}$ ) is not affected. The 2011-2100 mean of annually summed seasonal rainfall is lower in summer than in winter for all scenarios (winter-summer differences between 12.7 and $75.5 \mathrm{~mm}$ ), except for Scenario VI, in which summer rainfall exceeds winter rainfall by $19.5 \mathrm{~mm}$ for an average year.

Seasonally averaged temperatures and summed rainfall amounts show trends between 2011 and 2100 in some scenarios (Figure 2). Although seasonal temperatures have significant linear trends between +0.01 and $+0.04{ }^{\circ} \mathrm{C} \mathrm{yr}^{-1}$ in all scenarios (strongest trends in Scenarios I, IV, and VI), the trend in rainfall is significant only for the winters of Scenarios $\mathrm{I}\left(+0.68 \mathrm{~mm} \mathrm{yr}^{-1}\right)$, IV $\left(+0.90 \mathrm{~mm} \mathrm{yr}^{-1}\right)$, and VI $(+1.39 \mathrm{~mm}$ $\left.\mathrm{yr}^{-1}\right)$ and for the summers of Scenarios IV $\left(-0.60 \mathrm{~mm} \mathrm{yr}^{-1}\right)$ and VI $\left(+0.92 \mathrm{~mm} \mathrm{yr}^{-1}\right)$. Significance was determined with the Mann-Kendall trend test (significance level $=95 \%$ ).

Piezometer observations of the deep pressure heads beneath Pewsum near the Freepsumer Meer (location of the piezometer in Figure 1a) between 1990 and 2014 showed no significant trend. Although a trend might be expected due to the observed sea level rise during the same time (Nerem et al., 2018). In addition, we simulated deep pressure heads and salinities near the study site using the regional hydrological model GSFLOW (Markstrom, Niswonger, Regan, Prudic, $\&$ Barlow, 2008) with coupled groundwater and surface water flow, driven by the climate Scenarios I and II and a rising sea level. Sea-level-rise scenarios were based on Horton, Rahmstorf, Engelhart, and Kemp (2014) and take land subsidence as an effect of peat degradation and clay shrinkage (Oude Essink et al., 2010), as well as isostatic equalization movement (Vinka, Steffen, Engelhart, Reinhardt, \& Kaufmann, 2007), into account. The worst-case scenario with a sea-level rise of $150 \mathrm{~cm}$ between 2000 and 2100 included the melting of the polar glaciers (Bamber, Oppenheimer, Kopp, Aspinall, $\&$ Cooke, 2019). The pressure head differences between the 


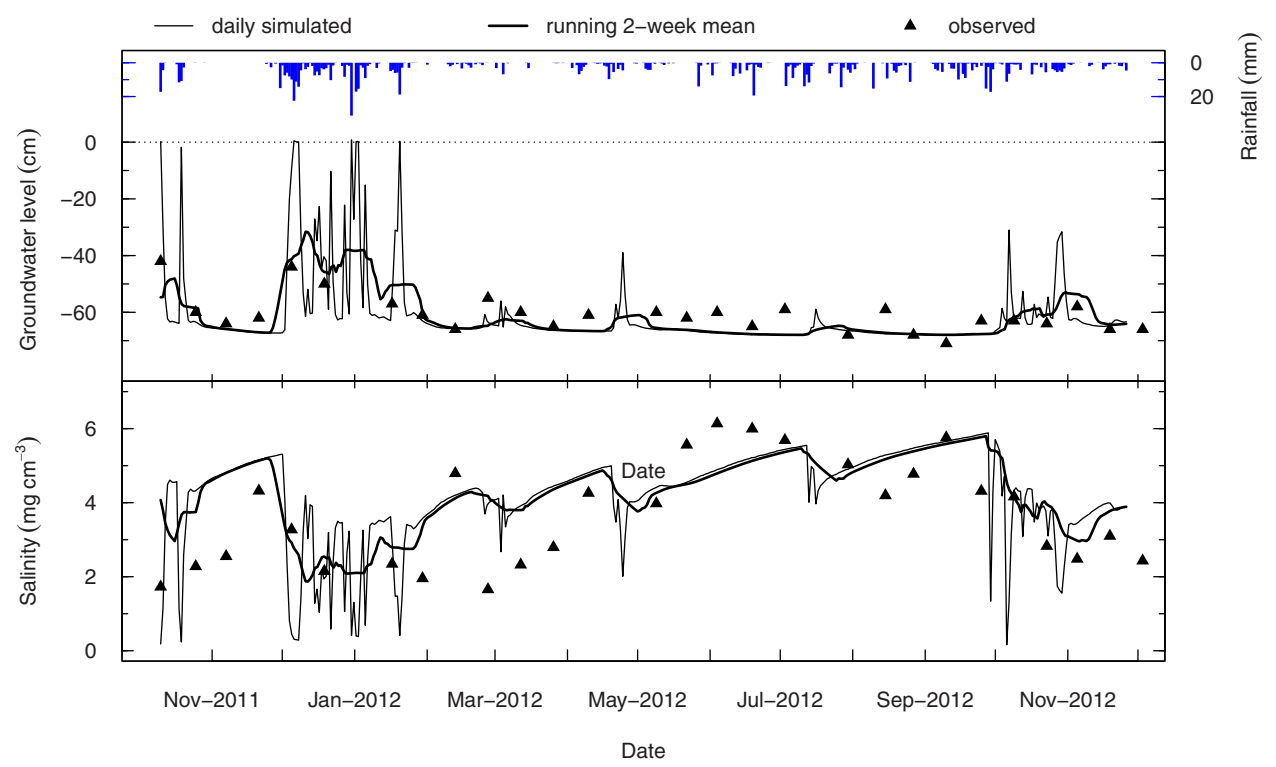

F I G U R E 3 Results of the calibrated model for groundwater level and salinity at groundwater level

simulations with assumed sea-level rise of 0,80 , and $150 \mathrm{~cm}$ within the period of 2000-2100 were marginal (in the order of $10 \mathrm{~cm}$ at the end of this period). This change in deep pressure heads through sea level rise was found to have no effect on the simulated salinities at our model site and was therefore neglected. We instead selected a 1-yr window of recorded pressure heads as permanently repeating boundary condition in the calibration.

\section{3 | RESULTS}

\section{1 | Calibration}

In the calibrated model results (Figure 3), both groundwater levels and salt concentrations lie within the observed ranges. The subseasonal dynamics are mostly well represented, especially during the winter months. In cases of rain scarcity, the model strongly overestimates salinities and underestimates groundwater levels.

\section{2 | Scenario runs}

In all scenario runs, annual means of solute concentration (Figure 4, left) show constant or increasing salinities below a depth of $-31.5 \mathrm{~cm}$. Annual mean salinity significantly increased at $-65 \mathrm{~cm}$ in Scenarios I, III, IV, and VI (Table 4). At $-31.5 \mathrm{~cm}$, only Scenarios III and IV lead to significant increases. In contrast, annual mean salinity in topsoil layers (i.e., above $-30 \mathrm{~cm}$ ) tends to decrease. This trend is significant at $-22 \mathrm{~cm}$ in Scenario VI only, whereas at $-10 \mathrm{~cm}$, Sce- narios I, IV, and VI show significant annual-mean decreases. Seasonal means of salinity show a similar behavior as the annual means with generally stronger declines in summer and stronger increases in winter. Stronger summer declines are even evident in Scenario IV, which involves increasing winter and decreasing summer rainfall. These seasonal features in salinity do not show at $-65 \mathrm{~cm}$, where differences between seasonal-mean trends are dissimilar. In Scenario V, only positive winter trends in depths between -41.5 and $-48 \mathrm{~cm}$ with comparably low rates are significant. Annual-mean surface salinity decreased in Scenarios I, IV, and VI.

Mean salinity at $-65 \mathrm{~cm}$ for the $2000-2099$ period is lower in the SRES Scenarios I and II than in the RCP scenarios. Conversely at $-10 \mathrm{~cm}$, it is higher in Scenarios I and II than in the other scenarios (Table 5). The difference between the SRES and RCP scenarios is also evident in the water balance (Figure 4, right), where Scenario I and II have higher groundwater levels and lower vertical fluxes (ET and bottom flux) than the RCP scenarios.

We quantified the intensity of salt stress on plants as exceedance frequency (i.e., the number of days per year on which daily mean salinity exceeds a certain value; Table 6). Significant trends in exceedance frequency between 2000 and 2099 resemble the trends in salinity (Table 4). Comparing the 10-yr mean frequencies of 2000-2009 and 2090-2099 for each case, we find the strongest trends to occur for 2 and $4 \mathrm{mg}$ $\mathrm{cm}^{-3}$ at -48 and $-65 \mathrm{~cm}$, respectively, in most scenarios.

Predictive analyses of the scenario runs using the PEST software (Doherty, 2010) gave an annual mean prediction uncertainty of $\pm 0.05 \mathrm{mg} \mathrm{cm}^{-3}$ at the end of 2099 for all soil layers. All significant trends are at rates outside the uncertainty range and are therefore quite certain. 

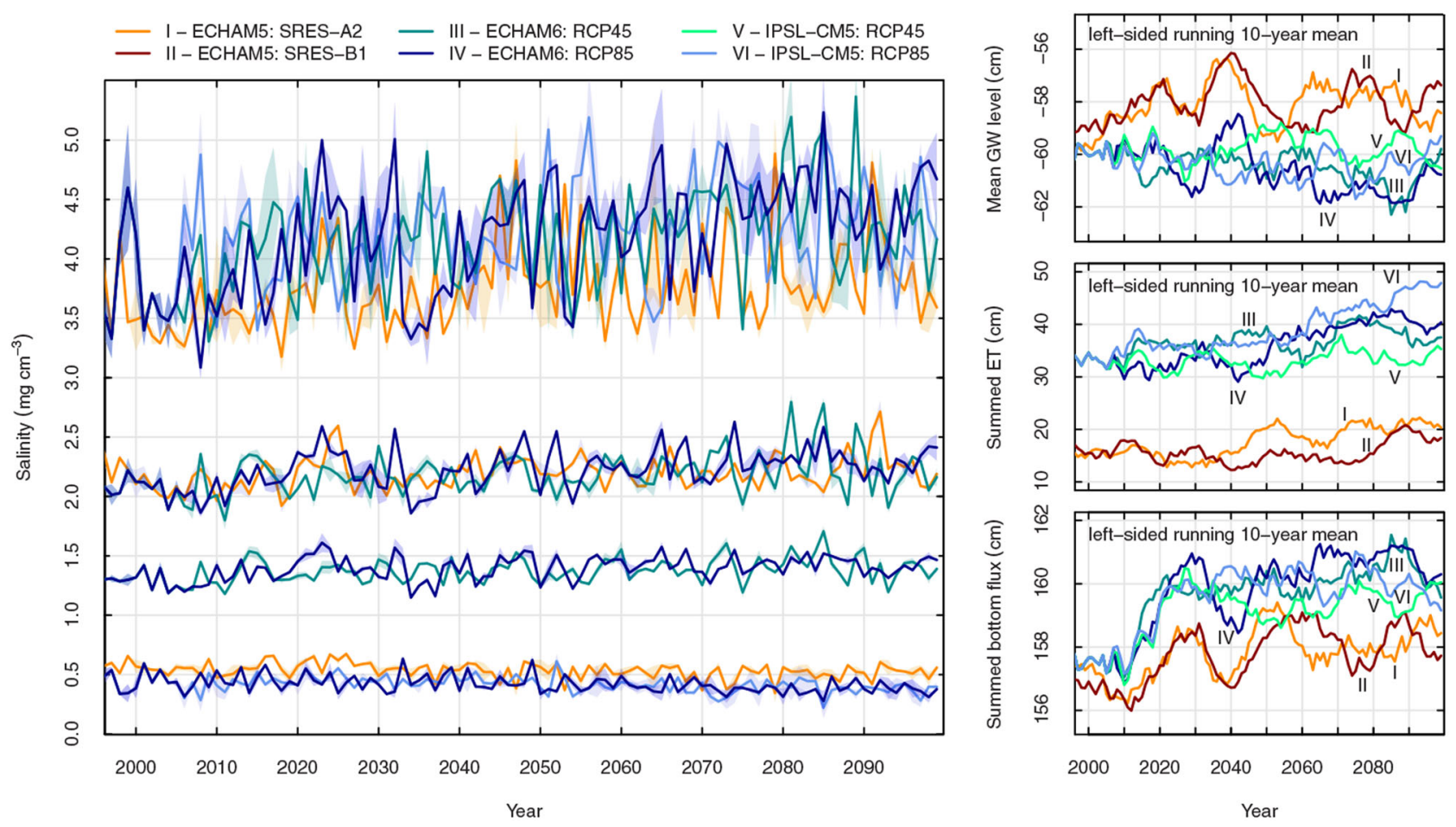

F I G U R E 4 A selection from the annual output of the scenario runs. Left: annual mean salinity shows positive or no (not shown) trends in layers at $-31.5 \mathrm{~cm}$ and below, whereas the upper layers above $-22 \mathrm{~cm}$ have negative or no (not shown) trends. Buffers around the graphs indicate the annual ranges between winter (lower) and summer (higher salinities) means. Right: annual mean (groundwater [GW] level) and annually summed (evapotranspiration [ET], bottom flux) water balance components indicate a strong dependence of the groundwater level on the bottom flux, since ET fluxes are comparably small. Note that water balance components are given in centimeters. RCP, Representative Concentration Pathway; SRES, Special Report on Emission Scenarios

\section{4 | DISCUSSION}

Comparing the mean seasonal rainfall in the calibration period and the scenarios (Figure 2) shows that all scenarios assume wetter summers than the calibration run, and winter rainfall does not decrease in any scenario. Therefore, the overestimation of salinity during dry periods in the calibration (Figure 3) only results in a small error in the scenario runs.

The results of all scenario runs indicate that rising salinity should not be expected in topsoil layers. Moreover, scenarios with increasing winter rainfall (Scenarios I, IV, and VI) lead to decreasing topsoil salinity. Although these scenarios include the strongest seasonal temperature increases affecting ET, the trend in winter rainfall seems to be a more important, if not the most important factor for the topsoil salt balance. This hypothesis is supported by the fact that salinity declines regardless of the summer rainfall trend (declining in Scenario IV, increasing in Scenario VI) and the mean summer rainfall (lower than winter in Scenario IV, higher in Scenario VI).

Of the SRES scenarios (Scenario I and II), which both involve an intermediate temperature increase within the range of the RCP scenarios, only Scenario I leads to significant trends in annual mean salinity, which are similar to yet lower trends in the other scenarios. Despite involving stronger sea- sonal temperature increases than Scenario III, salinity trends in Scenario I are weaker. It is very likely that, through ET, the higher mean summer temperature in Scenario III amplifies the positive salinity trend in subsoil. Another reason could be that Scenario I includes a significant positive trend in winter rainfall, where Scenario III does not. Thus, subsoil salinity might be affected by winter rainfall, as was already hypothesized for topsoil salinity. Nevertheless, Scenario I stands out through the high frequency of exceedance of $2 \mathrm{mg} \mathrm{cm}^{-3}$ at $-48 \mathrm{~cm}$ (Table 6) despite the similar trend in salinity and a similar mean salinity ( $>2 \mathrm{mg} \mathrm{cm}^{-3}$, Table 5) as other scenarios. This suggests a lower subannual variability in salt concentration, which is therefore another important factor determining salt stress.

Scenarios III and IV strongly differ in the radiative forcing and accordingly cause different salinity trends in the lower soil layers, as well as Scenarios V and VI. The main difference between the ECHAM6 and the IPSL-CM5 simulations lies in the opposed summer rainfall trends of Scenarios IV (negative) and VI (positive). Subsoil salinity trends agree with these differences in rainfall trends (Scenarios IV and VI in Table 4). General differences in the water balance and the vertical salinity gradient between the SRES and RCP scenarios can be attributed to differences in the summer means. Smaller 
T A B L E 4 Significant trends (2000-2099) of annual and seasonal mean salinity in scenario runs

\begin{tabular}{|c|c|c|c|c|c|c|c|}
\hline \multirow[b]{2}{*}{ Depth } & \multirow[b]{2}{*}{ Season } & \multicolumn{6}{|l|}{ Scenario } \\
\hline & & I & II & III & IV & $\mathbf{V}$ & VI \\
\hline \multicolumn{2}{|l|}{$\mathrm{cm}$} & \multicolumn{6}{|c|}{$\mathrm{mg} \mathrm{cm}^{-3} 100 \mathrm{yr}^{-1}$} \\
\hline \multirow{2}{*}{-0.25} & Winter & $-0.0514 * *$ & ns & ns & $-0.0583 * *$ & ns & $-0.0460 *$ \\
\hline & Summer & $-0.0540^{*}$ & ns & $-0.0497 *$ & $-0.0978 * *$ & $\mathrm{~ns}$ & $-0.0902 * *$ \\
\hline-10.00 & Summer & $-0.0665^{*}$ & ns & ns & $-0.1180 * *$ & $\mathrm{~ns}$ & $-0.1149 * *$ \\
\hline \multirow[t]{3}{*}{-22.00} & Annual & ns & ns & ns & ns & ns & $-0.0607 * *$ \\
\hline & Winter & $-0.0470 *$ & $\mathrm{~ns}$ & ns & $\mathrm{ns}$ & $\mathrm{ns}$ & $-0.0547^{*}$ \\
\hline & Summer & $\mathrm{ns}$ & ns & $\mathrm{ns}$ & $\mathrm{ns}$ & $\mathrm{ns}$ & $-0.0666^{* *}$ \\
\hline \multirow[t]{3}{*}{-41.50} & Annual & $+0.0863 *$ & $\mathrm{~ns}$ & $+0.1559^{* *}$ & $+0.1814 * *$ & $\mathrm{~ns}$ & $\mathrm{~ns}$ \\
\hline & Winter & $+0.0996^{* *}$ & $\mathrm{~ns}$ & $+0.1645^{* *}$ & $+0.2119 * *$ & $+0.0889 * *$ & $\mathrm{~ns}$ \\
\hline & Summer & ns & ns & $+0.1474^{*}$ & $+0.1509^{* *}$ & ns & ns \\
\hline \multirow[t]{3}{*}{-48.00} & Annual & $+0.1356^{* *}$ & $\mathrm{~ns}$ & $+0.1959 * *$ & $+0.2399 * *$ & $\mathrm{~ns}$ & $\mathrm{~ns}$ \\
\hline & Winter & $+0.1559 * *$ & $\mathrm{~ns}$ & $+0.2173 * *$ & $+0.2930 * *$ & $+0.1205^{* *}$ & ns \\
\hline & Summer & $\mathrm{ns}$ & ns & n. s. & $+0.1870^{* *}$ & $\mathrm{~ns}$ & $\mathrm{~ns}$ \\
\hline \multirow[t]{3}{*}{-65.00} & Annual & $+0.4291 * *$ & $\mathrm{~ns}$ & $+0.5734 * *$ & $+0.8729 * *$ & ns & $+0.4504 * *$ \\
\hline & Winter & $+0.4097 * *$ & $+0.1863 *$ & $+0.5345^{* *}$ & $+0.8969 * *$ & $\mathrm{~ns}$ & $+0.3934^{*}$ \\
\hline & Summer & $+0.4483^{* *}$ & ns & $+0.6120^{* *}$ & $+0.8491 * *$ & ns & $+0.5070^{* *}$ \\
\hline
\end{tabular}

${ }^{a}$ ns, not significant.

*** Significant at the .05 and .01 probability levels.

T A B L E 5 The 2000-2099 mean salinity in scenario runs

\begin{tabular}{lllllll} 
& \multicolumn{6}{l}{ Scenario } \\
\cline { 2 - 7 } Depth & I & II & III & IV & V & VI \\
\cline { 2 - 7 } $\mathrm{cm}$ & & & \multicolumn{4}{l}{$\mathrm{mg} \mathrm{cm}^{-3}$} \\
-10.0 & 0.5331 & 0.5573 & 0.4215 & 0.4205 & 0.4389 & 0.4195 \\
-31.5 & 1.4049 & 1.4318 & 1.3753 & 1.3961 & 1.3166 & 1.3738 \\
-48.0 & 2.1963 & 2.2218 & 2.1858 & 2.2288 & 2.0802 & 2.2418 \\
-65.0 & 3.7603 & 3.7213 & 4.1521 & 4.1861 & 3.9296 & 4.1859 \\
\hline
\end{tabular}

rainfall amounts in the SRES scenarios involve less dilution of upper soil water and thus higher topsoil salinity. Temperature differences might contribute to subsoil salinity, as higher ET rates in the RCP scenarios imply a higher bottom flux (Figure 4, right) and stronger subsoil salinization.

Plots of water balance (Figure 4, right) indicate that of the boundary fluxes (ET, bottom flux, drainage flux), bottom flux is the most important to the salt balance, since ET is small and drainage flux is governed mainly by bottom flux, rainfall, and groundwater management.
Salinization may affect future land use through changes in plant species communities. In Scenario IV, the days per year with $>4 \mathrm{mg} \mathrm{cm}^{-3}$ increase from an average of $94.7 \mathrm{~d} \mathrm{yr}^{-1}$ in 2000-2009 to $196.1 \mathrm{~d} \mathrm{yr}^{-1}$ in 2090-2099 (Table 6). The occurrence of higher salinities $\left(>6 \mathrm{mg} \mathrm{cm}^{-3}\right)$ even increases from (almost) 0 (2000-2009) to 9.9 and $31.8 \mathrm{~d} \mathrm{yr}^{-1}$ (20902099), in Scenarios III and IV, respectively, thus representing a relatively new potential stress on the plant community. However, most scenarios predict salinity increases only in soil layers below $-40 \mathrm{~cm}$ (i.e., outside the rooting zone of most grassland species). Therefore, we do not expect immediate impacts of the salinity changes on the biomass production of the vegetation. The vegetation composition is managed by the local farmers and consists mainly of salt-intolerant grassland species (Table 7).

Although we do not expect these effects based on our simulations, future changes in water management would lead to changes of not only groundwater levels but also salinity. The COMTESS project investigates four alternative land management options, which include a polder in the 
T A B L E 6 Significant trends in exceedance frequency

\begin{tabular}{|c|c|c|c|c|c|c|c|}
\hline \multirow[b]{2}{*}{ Salinity } & \multirow[b]{2}{*}{ Depth } & \multicolumn{6}{|l|}{ Scenario } \\
\hline & & $\overline{\mathbf{I}}$ & II & III & IV & $\mathbf{V}$ & VI \\
\hline $\mathrm{mg} \mathrm{cm}^{-3}$ & $\mathrm{~cm}$ & 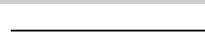 & & 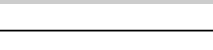 & $-\mathrm{d} \mathrm{yr}^{-1}$ & & \\
\hline \multirow[t]{2}{*}{2} & -41.5 & $\mathrm{~ns}^{\mathrm{a}}$ & ns & $(19.9 ; 45.2)^{*}$ & $(9.7 ; 51.6)^{* *}$ & ns & ns \\
\hline & -48.0 & $(266 ; 337.3)^{* *}$ & ns & $(192.2 ; 289.7)^{* *}$ & $(182.6 ; 345.9)^{* *}$ & $(200.5 ; 296.6)^{*}$ & ns \\
\hline 4 & -65.0 & $(31.4 ; 125.6)^{* *}$ & ns & $(98.1 ; 163.3)^{* * *}$ & $(94.7 ; 196.1)^{* *}$ & ns & $(128.2 ; 174.6)^{* *}$ \\
\hline 6 & -65.0 & ns & ns & $(0 ; 9.9)^{* *}$ & $(2.7 ; 31.8)^{* *}$ & ns & $(11.7 ; 20.3)^{*}$ \\
\hline
\end{tabular}

Note. Values in parentheses indicate mean frequencies for the periods of 2000-2009 and 2090-2099, respectively.

${ }^{\mathrm{a}} \mathrm{ns}$, not significant.

*** Significant at the .05 and .01 probability levels.

Freepsumer Meer where our study plots are located (Karrasch et al., 2017). Should groundwater levels and salinity rise, the species composition on our plots will likely shift toward more salt-tolerant species in the regional species pool. Halophytes overcome osmotic stress with the help of N-rich osmoprotectants (Rozema, Bijwaard, Prast, \& Broekman, 1985; Steward, Larher, Ahmand, \& Lee, 1979), which leads to their high forage value. Although salt marshes are considered as very productive and providing high-value fodder (Bakker et al., 1993), their productivity and fodder quality depend on salinity level and species composition (Masters, Revell, \& Norman, 2010; Rogers et al., 2005). In addition, the accumulation of salts might, under certain conditions, cause depressed feed intake and even compromise animal health (Masters et al., 2007).

Relating to animal health, salinization of ditch water may become a problem for pasture farming if thresholds for drinking water of livestock recommended by the German Federal Ministry for Food and Agriculture $\left(3 \mathrm{mS} \mathrm{cm}{ }^{-1}\right.$; Kamphues et al., 2007; $1.62 \mathrm{mg} \mathrm{cm}^{-3}$ according to our regression) are exceeded. In this case, farmers need to find logistic solutions for purchasing water, thus reducing the profit from pasture farming. However, our model results of the lateral drainage salinity do not indicate a distinct trend for the 2000-2099 period (not shown). We therefore assume that this case is not likely.

As climate change and sea level rise interact with intensive land use in European coastal landscapes, further research into the influence of increasing salinity in the subsoil on future sustainable land management is necessary.

Our results suggest that a long-term climate change toward higher temperatures implies slowly rising salt concentrations and thereby rising exceedance frequencies of critical thresholds in the subsoil of the Freepsumer Meer. These trends were mostly significant in projections driven by four out of six weather scenarios with different trends (winter positive, summer positive; winter positive, summer negative; no trends) of seasonal rainfall. The salinity in the topsoil, however, is expected to decrease or stay constant. We detected the trend in winter rainfall as a main factor affecting the near-surface salt balance. Subsoil salinity trends could be attributed to both winter rainfall and mean summer temperature. Absolute salinity in both top- and subsoil showed a dependence on summer rainfall and temperature through dilution and ET, as was shown for substantial differences in climate variables between scenarios. Comparison between one SRES and different RCP scenarios showed that similar mean salinity and salinity trends

T A B L E 7 Salt indicator values of species occurring on the model site (Cebrián-Piqueras, Karrasch, \& Kleyer, 2017)

\section{Species}

Agrostis stolonifera L.

Alopecurus geniculatus L.

Alopecurus pratensis $\mathrm{L}$.

Dactylis glomerata L.

Elymus repens (L.) Gould

Festuca rubra L.

Glyceria fluitans (L.) R.Br.

Lolium perenne $\mathrm{L}$.

Phragmites australis (Cav.) Trin. ex Steud.

Ranunculus repens $\mathrm{L}$.

Trifolium repens $\mathrm{L}$.
Ellenberg salt indicator value $(S)^{\mathrm{a}}$

0 (glycophyte)

2 (oligohaline, $0.05-0.3 \% \mathrm{Cl}^{-}$)

0 (glycophyte)

0 (glycophyte)

0 (glycophyte)

0 (glycophyte)

0 (glycophyte)

0 (glycophyte)

2 (oligohaline, $\left.0.05-0.3 \% \mathrm{Cl}^{-}\right)^{\mathrm{b}}$

1 (salt-tolerant, $\leq 1.9 \mathrm{mg} \mathrm{cm}^{-3}$ )

1 (salt-tolerant, $\leq 1.9 \mathrm{mg} \mathrm{cm}^{-3}$ )

${ }^{a}$ Ellenberg and Leuschner (2010).

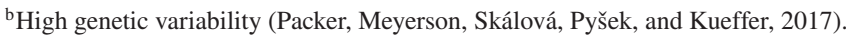


can result in different magnitudes of salt stress for plants, for which we found positive subsoil trends in most scenarios.

At the soil surface, the projections show only minimal changes in the salt concentrations until 2100. Therefore, land management plans should consider how the strongest changes in salinity, which in our simulations occur between -50 and $-60 \mathrm{~cm}$ relative to the surface, might affect the vegetation and the use of water. Based on our simulations, we would expect changes in the plant community only if future management allowed groundwater levels to rise. In this case, possible repercussions on the fodder quality are diverse and difficult to estimate, whereas pasture farmers might suffer a loss of livestock drinking water from ditches.

\section{ACKNOWLEDGMENTS}

We thank the COMTESS group (Miguel Cebrián-Piqueras, Juliane Trinogga, Martin Maier, Michael Kleyer) for maintenance, sampling campaigns, and supply; the water board I. Entwässerungsverband Emden, especially Jan van Dyk; and the environmental agency field office Aurich (Niedersächsischer Landesbetrieb Wasserwirtschaft, Küsten und Naturschutz, NLWKN), especially Anke Joritz for data and support. We, A.S .and T.G., acknowledge the funding by the German Federal Ministry of Education and Research as part of the collaborative research project "Sustainable coastal land management: Trade-offs in ecosystem services COMTESS" (Grant no. 01LL0911). We acknowledge support by the German Research Foundation and the Open Access Publication Funds of the Technische Universität Braunschweig.

\section{CONFLICT OF INTEREST}

The authors declare no conflict of interest.

\section{ORCID}

Julius Eberhard iD https://orcid.org/0000-0003-2202-4778

N. Loes M.B. van Schaik

https://orcid.org/0000-0002-5742-2859

Anett Schibalski (iD https://orcid.org/0000-0002-1686-8811

Thomas Gräff iD https://orcid.org/0000-0003-1164-586X

\section{R E F E R E N CES}

Bakker, J., de Leeuw, J., Dijkema, K., Leendertse, P., Prins, H., \& Rozema, J. (1993). Salt marshes along the coast of the Netherlands. Hydrobiologia, 265, 73-95. https://doi.org/10.1007/BF00007263

Bamber, J., Oppenheimer, M., Kopp, R., Aspinall, W., \& Cooke, R. (2019). Ice sheet contributions to future sea-level rise from structured expert judgment. Proceedings of the National Academy of Sciences of the United States of America, 116, 11195-11200. https://doi.org/10.1073/pnas.1817205116

Bartholomeus, R., Stagge, J., Tallaksen, L., \& Witte, J. (2015). Sensitivity of potential evaporation estimates to 100 years of climate variability. Hydrology and Earth System Sciences, 19, 997-1014. https://doi.org/10.5194/hess-19-997-2015
Boesten, J., \& Stroosnijder, L. (1986). Simple model for daily evaporation from fallow tilled soil under spring conditions in a temperate climate. Netherlands Journal of Agricultural Science, 34, 75-90.

Bonfante, A., Impagliazzo, A., Fiorentino, N., Langella, G., Mori, M., \& Fagnano, M. (2017). Supporting local farming communities and crop production resilience to climate change through giant reed (Arundo donax L.) cultivation: An Italian case study. Science of the Total Environment, 601-602, 603-613. https://doi.org/10.1016/j.scitotenv.2017.05.214

Bürger, G. (1996). Expanded downscaling for generating local weather scenarios. Climate Research, 7, 111-128. https://doi.org/ $10.3354 / \mathrm{cr} 007111$

Cebrián-Piqueras, M., Karrasch, L., \& Kleyer, M. (2017). Coupling stakeholder assessments of ecosystem services with biophysical ecosystem properties reveals importance of social contexts. Ecosystem Services, 23, 108-115. https://doi.org/10.1016/j.ecoser. 2016.11.009

Colombani, N., Mastrocicco, M., \& Giambastiani, B. (2015). Predicting salinization trends in a lowland coastal aquifer: Comacchio (Italy). Water Resource Management, 29, 603-618. https://doi.org/10.1007/s11269-014-0795-8

Dai, Y., Shangguan, W., \& Duan, Q. (2013). Development of a China dataset of soil hydraulic parameters using pedotransfer functions for land surface modeling. Journal of Hydrometeorology, 14, 869-887. https://doi.org/10.1175/JHM-D-12-0149.1

de Louw, P., Eeman, S., Oude Essink, G., Vermue, E., \& Post, V. (2013). Rainwater lens dynamics and mixing between infiltrating rainwater and upward saline groundwater seepage beneath a tiledrained agricultural field. Journal of Hydrology, 501, 133-145. https://doi.org/10.1016/j.jhydrol.2013.07.026

de Louw, P., Oude Essink, G., Stuyfzand, P., \& van der Zee, S. (2010). Upward groundwater flow in boils as the dominant mechanism of salinization in deep polders, the Netherlands. Journal of Hydrology, 394, 494-506. https://doi.org/10.1016/j.jhydrol.2010.10.009

de Louw, P., van der Velde, Y., \& van der Zee, S. (2011). Quantifying water and salt fluxes in a lowland polder catchment dominated by boil seepage: A probabilistic end-member mixing approach. Hydrology and Earth System Sciences, 15, 2101-2117. https://doi.org/10.5194/hess-15-2101-2011

Delsman, J., de Louw, P., de Lange, W., \& Oude Essink, G. (2017). Fast calculation of groundwater exfiltration salinity in a lowland catchment using a lumped celerity/velocity approach. Environmental Modelling \& Software, 96, 323-334. https://doi.org/10.1016/j.envsoft.2017.07.004

Doherty, J. (2010). PEST: Model independent parameter estimation, user manual. Brisbane, QLD, Australia: Watermark Numerical Computing.

Dufresne, J.-L., Foujols, M.-A., Denvil, S., Caubel, A., Marti, O., Aumont, O., ... Vuichard, N. (2013). Climate change projections using the IPSL-CM5 Earth System Model: From CMIP3 to CMIP5. Climate Dynamics, 40, 2123-2165. https://doi.org/10.1007/s00382-012-1636-1

Ellenberg, H., \& Leuschner, C. (2010). Vegetation Mitteleuropas mit den Alpen. Stuttgart, Germany: Eugen Ulmer.

Fedoroff, N., Battisti, D., Beachy, R., Cooper, P., Fischhoff, D., Hodges, C., ... Zhu, J.-K. (2010). Radically rethinking agriculture for the 21st century. Science, 327, 833-834. https://doi.org/10.1126/science.1186834 
Flowers, T. (2004). Improving crop salt tolerance. Journal of Experimental Botany, 55, 307-319. https://doi.org/10.1093/jxb/erh003

Ghassemi, F., Jakeman, A., \& Nix, H. (1995). Salinisation of land and water resources: Human causes, extent, management and case studies. Wallingford, UK: CAB International.

Glenn, E., Brown, J., \& Blumwald, E. (1999). Salt tolerance and crop potential of halophytes. Critical Reviews in Plant Sciences, 18, 227 255. https://doi.org/10.1080/07352689991309207

Haque, S. (2006). Salinity problems and crop production in coastal regions of Bangladesh. Pakistan Journal of Botany, 38, 1359-1365.

Herbert, E., Boon, P., Burgin, A., Neubauer, S., Franklin, R., Ardón, M., ... Gell, P. (2015). A global perspective on wetland salinization: Ecological consequences of a growing threat to freshwater wetlands. Ecosphere, 6, 1-43. https://doi.org/10.1890/ES14-00534.1

Horton, B., Rahmstorf, S., Engelhart, S., \& Kemp, A. (2014). Expert assessment of sea-level rise by AD 2100 and AD 2300. Quaternary Science Reviews, 84, 1-6. https://doi.org/10.1016/ j.quascirev.2013.11.002

Jiménez Cisneros, B., Oki, T., Arnell, N., Benito, G., Cogley, J., Döll, P., ... Mwakalila, S. S. (2014). Freshwater resources. In C. B. Field et al., (Eds.), Climate change 2014: Impacts, adaptation, and vulnerability. Part A: Global and sectoral aspects. Contribution of Working Group II to the Fifth Assessment Report of the Intergovernmental Panel on Climate Change (pp. 229-269). Cambridge, UK: Cambridge University Press.

Kamphues, J., Böhm, R., Flachowsky, G., Lahrssen-Wiederholt, M., Meyer, U., \& Schenkel, H. (2007). Empfehlungen zur Beurteilung der hygienischen Qualität von Tränkwasser für Lebensmittel liefernde Tiere unter Berücksichtigung der gegebenen rechtlichen rahmenbedin gungen. Landbauforschung Völkenrode, 57, 255-272.

Karrasch, L., Maier, M., Klenke, T., \& Kleyer, M. (2017). Collaborative landscape planning: Co-design of ecosystem-based land management scenarios. Sustainability, 9(9). https://doi.org/10.3390/su9091668

Kim, Y., Lee, K.-S., Koh, D.-C., Lee, D.-H., Lee, S.-G., Park, W.B., ... Woo, N.-C. (2003). Hydrogeochemical and isotopic evidence of groundwater salinization in a coastal aquifer: A case study in Jeju volcanic island, Korea. Journal of Hydrology, 270, 282-294. https://doi.org/10.1016/S0022-1694(02)00307-4

Kliesch, S., Behr, L., Salzmann, T., \& Miegel, K. (2016). Simulation des Grundwasserhaushalts in ausgewählten Niederungsgebieten an der deutschen Ostseeküste. Hydrologie und Wasserbewirtschaftung, 60, $108-118$.

Kroes, J., van Dam, J., Groenendijk, P., Hendriks, R., \& Jacobs, C. (2008). SWAP version 3.2. Theory description and user manual. Wageningen, the Netherlands: Alterra.

Kroes, J., Wesseling, J., \& van Dam, J. (2000). Integrated modelling of the soil-water-atmosphere-plant system using the model SWAP 2.0 an overview of theory and an application. Hydrological Processes, 14, 1993-2002. https://doi.org/10.1002/10991085(20000815/30)14:11/12<1993::AID-HYP50>3.0.CO;2-\%23

Kumar, P., Sarangi, A., Singh, D., Parihar, S., \& Sahoo, R. (2015). Simulation of salt dynamics in the root zone and yield of wheat crop under irrigated saline regimes using SWAP model. Agricultural Water Management, 148, 72-83. https://doi. org/10.1016/j.agwat.2014.09.014

Maas, E., \& Grattan, S. (1999). Crop yields as affected by salinity. In R. Skaggs \& J. van Schilfgaarde (Eds.), Agricultural drainage (pp. 55-108). Madison, WI: ASA, CSSA, and SSSA. https://doi.org/10.2134/agronmonogr38.c3
Maas, E., \& Hoffman, G. (1977). Crop salt tolerance: Current assessment. Journal of the Irrigation and Drainage Division, 103, 115-134.

Markstrom, S., Niswonger, R., Regan, R., Prudic, D., \& Barlow, P. (2008). GSFLOW: Coupled ground-water and surface-water flow model based on the integration of the precipitation-runoff modeling system (PRMS) and the modular ground-water flow model (MODFLOW-430 2005) (Technical report). Reston, VA: USGS.

Masters, D., Benes, S., \& Norman, H. (2007). Biosaline agriculture for forage and livestock production. Agriculture Ecosystems \& Environment, 119, 234-248. https://doi.org/10.1016/j.agee.2006.08.003

Masters, D., Revell, D., \& Norman, H. (2010). Managing livestock in degrading environments. In N. E. Odongo, M. Garcia, \& G. J. Viljoen (Eds.), Sustainable improvement of animal production and health (pp. 255-268). Rome: FAO.

McWilliam, J. (1986). The national and international importance of drought and salinity effects on agricultural production. Australian Journal of Plant Physiology, 13, 1-13. https://doi.org/10.1071/PP9860001

Miegel, K., Gräff, T., Selle, B., Salzmann, T., Franck, C., \& Bronstert, A. (2016). Investigation of a renaturated fen on the Baltic Sea coast of Mecklenburg-Part I: System description and basic hydrological characterisation. Hydrologie und Wasserbewirtschaftung, 60, 242258 .

Minacapilli, M., Agnese, C., Blanda, F., Cammalleri, C., Ciraolo, G., D'Urso, G., ... Rallo, G. (2009). Estimation of actual evapotranspiration of Mediterranean perennial crops by means of remote-sensing based surface energy balance models. Hydrology and Earth System Sciences, 13, 1061-1074. https://doi.org/10.5194/hess-13-10612009

Monteith, J. (1965). Evaporation and environment. Symposia of the Society for Experimental Biology, 19, 205-224.

Moss, R., Babiker, M., Brinkman, S., Calvo, E., Carter, T., Edmonds, J., \& Zurek, M. (2008). Towards new scenarios for analysis of emissions, climate change, impacts, and response strategies (Technical report). Geneva: IPCC.

Mualem, Y. (1976). A new model for predicting the hydraulic conductivity of unsaturated porous media. Water Resources Research, 12, 513-522. https://doi.org/10.1029/WR012i003p00513

Nakićenović, N., \& Swart, R. (2000). Special report on emissions scenarios: A special report of Working Group III of the Intergovernmental Panel on Climate Change. Cambridge, UK: Cambridge University Press.

Nerem, R., Beckley, B., Fasullo, J., Hamlington, B., Masters, D., \& Mitchum, G. (2018). Climate-change-driven accelerated sea-level rise detected in the altimeter era. Proeedings of the National Academy of Sciences of the United States of America, 115, 2022-2025. https://doi.org/10.1073/pnas.1717312115

Oude Essink, G., van Baaren, E., \& de Louw, P. (2010). Effects of climate change on coastal groundwater systems: A modeling study in the Netherlands. Water Resources Research, 46(10). https://doi.org/10.1029/2009WR008719

Packer, J., Meyerson, L., Skálová, H., Pyšek, P., \& Kueffer, C. (2017). Biological flora of the British Isles: Phragmites australis. Journal of Ecology, 105, 1123-1162. https://doi.org/10.1111/1365-2745.12797

Panta, S., Flowers, T., Lane, P., Doyle, R., Haros, G., \& Shabala, S. (2014). Halophyte agriculture: Success stories. Environmental and Experimental Botany, 107, 71-83. https://doi.org/ 10.1016/j.envexpbot.2014.05.006 
Pauw, P., van Baaren, E., Visser, M., de Louw, P., \& Oude Essink, G. (2015). Increasing a freshwater lens below a creek ridge using a controlled artificial recharge and drainage system: A case study in the Netherlands. Hydrogeology Journal, 23, 1415-1430. https://doi.org/10.1007/s10040-015-1264-z

Pitman, M., \& Läuchli, A. (2002). Global impact of salinity and agricultural ecosystems. In A. Läuchli \& U. Lüttge (Eds.), Salinity: Environment-plants-molecules (pp. 3-20). Dordrecht, the Netherlands: Springer.

Rawls, W., \& Brakensiek, D. (1985). Prediction of soil water properties for hydrologic modeling. In E. B. Jones \& T. J. Ward (Eds.), Watershed management in the eighties: Proceedings of the symposium sponsored by the Committee on Watershed Management of the Irrigation and Drainage Division of the American Society of Civil Engineers in conjunction with the ASCE convention (pp. 293-299). Reston, VA: American Society of Civil Engineers.

Rengasamy, P. (2006). World salinization with emphasis on Australia. Journal of Experimental Botany, 57, 1017-1023. https://doi.org/10.1093/jxb/erj108

Richards, L. (1931). Capillary conduction of liquids through porous mediums. Journal of Applied Physics, 1, 318-333. https://doi. org/10.1063/1.1745010

Roeckner, E., Baeuml, G., Bonaventura, L., Brokopf, R., Esch, M., Giorgetta, M., ... Tompkins, A. (2003). The atmospheric general circulation model ECHAM5-Part 1: Model description (Technical report) Hamburg, Germany: Max Planck Institute for Meteorology.

Rogers, M., Craig, A., Munns, R., Colmer, T., Nichols, P., Malcolm, C., ... Ewing, M. A. (2005). The potential for developing fodder plants for the salt-affected areas of southern and eastern Australia: An overview. Australian Journal of Experimental Agriculture, 45, 301-329.

Rozema, J., Bijwaard, P., Prast, G., \& Broekman, R. (1985). Ecophysiological adaptations of coastal halophytes from foredunes and salt marshes. Vegetatio, 62, 499-521. https://doi.org/10.1007/ BF00044777

Rozema, J., \& Flowers, T. (2008). Crops for a salinized world. Science, 322, 1478-1480. https://doi.org/10.1126/science.1168572

Rühlmann, J., Körschens, M., \& Graefe, J. (2005). A new approach to calculate the particle density of soils considering properties of the soil organic matter and the mineral matrix. Geoderma, 130, 272-283. https://doi.org/10.1016/j.geoderma.2005.01.024

Schipper, P., Groenendijk, P., van Eekeren, N., van Zanen, M., Rozemeijer, J., Jansen, G., \& Swart, B. (2015). Goede grond voor een duurzaam watersysteem (Technical report). Amersfoort, the Netherlands: Applied Water Research Foundation.

Solomon, R., Miron, J., Ben-Ghedalia, D., \& Zomberg, Z. (1995). Performance of high producing dairy cows offered drinking water of high and low salinity in the Arava Desert. Journal of Dairy Science, 78, 620-624. https://doi.org/10.3168/jds.S0022-0302(95)76672-3

Spekat, A., Kreienkamp, F., \& Enke, W. (2010). An impact-oriented classification method for atmospheric patterns. Physics and Chemistry of the Earth, 35, 352-359. https://doi.org/10.1016/j.pce.2010.03. 042

Stevens, B., Giorgetta, M., Esch, M., Mauritsen, T., Crueger, T., Rast, S., ... Roeckner, E. (2013). Atmospheric component of the MPI-M earth system model: ECHAM6. Journal of Advances in Modeling Earth Systems, 5, 1-27. https://doi.org/10.1002/jame.20015
Steward, G., Larher, F., Ahmand, I., \& Lee, J. (1979). Nitrogen metabolism and salt tolerance in higher plants: Halophytes. In R. Jefferies \& A. Davy (Eds.), Ecological processes in coastal environments (pp. 229-241). Oxford, UK: Blackwell.

Streif, H. (1990). Das ostfriesische Küstengebiet. Stuttgart, Germany: Sammlung Geologischer Führer \& Gebrüder Borntraege.

Stuyfzand, P., \& Stuurman, R. (2008). Origin, distribution and chemical mass balances for brackish and saline groundwaters in the Netherlands. In G. Barrocu (Ed.), Proceedings of the 1st SWIM-SWICA Joint Saltwater Intrusion Conference (pp. 151-164). Salt Water Intrusion Meeting.

Taylor, S., \& Ashcroft, G. (1972). Physical edaphology. San Francisco, CA: W. H. Freeman and Company.

van Dam, J. (2000). Field-scale water flow and solute transport: SWAP model concepts, parameter estimation and case studies (PhD dissertation). Wageningen, the Netherlands: Wageningen University \& Research.

van Genuchten, M. Th. (1980). A closed-form equation for predicting the hydraulic conductivity of unsaturated soils. Soil Science Society of America Journal, 44, 892-898. https://doi.org/ 10.2136/sssaj1980.03615995004400050002x

Verry, E., Boelter, D., Päivänen, J., Nichols, D., Malterer, T., \& Gafni, A. (2011). Physical properties of organic soils. In R. Kolka, S. D. Sebestyen, E. S. Verry, \& K. N. Brooks (Eds.), Peatland biochemistry and watershed hydrology at the Marcell Experimental Fores (pp. 135-176). Boca Raton, FL: CRC Press.

Vinka, A., Steffen, H., Engelhart, S., Reinhardt, L., \& Kaufmann, G. (2007). Holocene relative sea-level change, isostatic subsidence and the radial viscosity structure of the mantle of northwest Europe (Belgium, the Netherlands, Germany, southern North Sea). Quaternary Science Reviews, 26, 3249-3275. https://doi.org/10.1016/j.quascirev.2007.07.014

Violette, S., Boulicot, G., \& Gorelick, S. (2009). Tsunami-induced groundwater salinization in southeastern India. Comptes Rendus Geoscience, 341, 339-346. https://doi.org/10.1016/j.crte. 2008.11.013

Waller, P., \& Harrison, A. (1986). A rapid method for the assessment of air-filled porosity and its relationship with other methods. Acta Horticulturae, 178, 107-114. https://doi.org/10.17660/ ActaHortic.1986.178.13

Weerts, J. (1996). Complex confining layers. 505 Architecture and hydraulic properties of Holocene and Late Weichselian deposits in the fluvial Rhine-Meuse delta, the Netherlands (PhD dissertation). Utrecht, the Netherlands: University of Utrecht.

Werner, A., Bakker, M., Post, V., Vandenbohede, A., Lu, C., AtaieAshtiani, B., ... Barry, D. (2013). Seawater intrusion processes, investigation and management: Recent advances and future challenges. Advances in Water Resources, 51, 3-26. https://doi.org/ 10.1016/j.advwatres.2012.03.004

Weynants, M., Vereecken, H., \& Javaux, M. (2009). Revisiting Vereecken pedotransfer functions: Introducing a closed-form hydraulic model. Vadose Zone Journal, 8, 86-95. https://doi.org/ 10.2136/vzj2008.0062

Wildvang, D. (1938). Die Geologie Ostfrieslands. Berlin: Preußische Geologische Landesanstalt. 
Williams, K., Ewel, K., Stumpf, R., Putz, F., \& Workman, T. (1999). Sealevel rise and coastal forest retreat on the west coast of Florida, USA. Ecology, 80, 2045-2063. https://doi.org/10.1890/0012-9658(1999) 080[2045:SLRACF]2.0.CO;2

Witte, S., \& Giani, L. (2016). Greenhouse gas emission and balance of marshes at the southern North Sea coast. Wetlands, 36, 121-132. https://doi.org/10.1007/s13157-015-0722-7

Wösten, J., Lilly, A., Nemes, A., \& le Bas, C. (1999). Development and use of a database of hydraulic properties of European soils. Geoderma, 90, 169-185. https://doi.org/10.1016/S0016-7061(98) 00132-3

Yamaguchi, T., \& Blumwald, E. (2005). Developing salt-tolerant crop plants: Challenges and opportunities. Trends in Plant Science, 10, 615-620. https://doi.org/10.1016/j.tplants.2005.10.002

Yensen, N. (2006). Halophyte uses for the twenty-first century. In M. Khan \& D. Weber (Eds.), Ecophysiology of high salinity tolerant plants (pp. 367-396). Dordrecht, the Netherlands: Springer.
Yeo, A. (1999). Predicting the interaction between the effects of salinity and climate change on crop plants. Scientia Horticulturae, 78, 159174. https://doi.org/10.1016/S0304-4238(98)00193-9

\section{SUPPORTING INFORMATION}

Additional supporting information may be found online in the Supporting Information section at the end of the article.

How to cite this article: Eberhard J, van Schaik NLMB, Schibalski A, Gräff T. Simulating future salinity dynamics in a coastal marshland under different climate scenarios. Vadose Zone J. 2020;19:e20008. https://doi.org/10.1002/vzj2.20008 